\title{
Interação entre resistência genética parcial e fungicidas no controle da ferrugem asiática da soja
}

\author{
Valdirene Aparecida Stabile Silva( ${ }^{(1)}$, Fernando Cezar Juliatti(1) e Luís Antônio Stabile Silva ${ }^{(2)}$
}

\begin{abstract}
(1)Universidade Federal de Uberlândia, Núcleo de Fitopatologia, Av. Amazonas, s/non, Campus Umuarama, Bloco 2E, CEP $38400-920$ Uberlândia, MG E-mail: valdirenesilva2000@yahoo.com.br, juliatti@ufu.br (2)Escola Superior de Agricultura Luiz de Queiroz, Dep. de Genética, Caixa Postal 83, CEP 13400-970 Piracicaba, SP. E-mail: stabilesilva@gmail.com
\end{abstract}

Resumo - O objetivo deste trabalho foi estudar a interação de diferentes cultivares de soja com fungicidas no controle da ferrugem asiática, em duas épocas de semeadura. O experimento foi realizado em condições de campo, de setembro de 2005 a maio de 2006. Foram analisadas as características: incidência, severidade (porcentagem de área foliar infectada e nota visual da parcela), número de pústulas por centímetro quadrado, peso de mil sementes e produtividade. A área abaixo da curva de progresso da doença (AACPD) foi calculada para os dados da doença. Foram observados efeitos significativos das cultivares, dos fungicidas, e da interação entre esses fatores, tanto nos valores de AACPD quanto no peso de mil sementes e produtividade. As cultivares IAC-100, Potenza e UFUS-Impacta apresentaram, em ambas as épocas de semeadura, a presença de resistência parcial à ferrugem asiática, evidenciada pelos valores baixos da AACPD. O fungicida do grupo dos triazóis (cyproconazole) e sua mistura com um fungicida do grupo das estrobilurinas (azoxystrobina e cyproconazole) apresentam controle eficiente sobre a ferrugem asiática.

Termos para indexação: Glycine max, Phakopsora pachyrhizi, doença foliar, epidemiologia.

\section{Interaction between partial genetic resistance and fungicides in the control of soybean Asian rust}

\begin{abstract}
The objective of this work was to analyze the interaction between cultivars and fungicides for soybean Asian rust control, in two sowing times. The experiment was carried out in field conditions, from September 2005 to May 2006. The following traits were analyzed: incidence, severity (percentage of infected leaf area and visual grading of the plot), number of pustules per square centimeter, weight of one thousand seeds and yield. The area under the disease progress curve (AUDPC) was calculated for disease data. Significant effects were observed for cultivars, fungicides, and the interaction between these factors for AUDPC, as well as for weight of one thousand seeds and yield. The cultivars IAC-100, Potenza and UFUS-Impacta, in both sowing times, presented partial resistance to Asian rust, which was highlighted by the low values of AUDPC. The triazole group fungicide cyproconazole and its mixture with the strobilurin group fungicide azoxystrobin were effective on Asian rust control.
\end{abstract}

Index terms: Glycine max, Phakopsora pachyrhizi, foliar diseases, epidemiology.

\section{Introdução}

Entre os principais fatores que limitam o rendimento, a lucratividade e o sucesso da produção de soja destacam-se as doenças (Juliatti et al., 2004). Mundialmente, são listadas mais de 100 doenças na cultura da soja (Sinclair \& Backman, 1989), das quais aproximadamente 50 já foram identificadas no Brasil.

Plantas severamente infestadas com a ferrugem asiática da soja (Phakopsora pachyrhizi Sydow) apresentam desfolha precoce, o que compromete a formação, o enchimento de vagens e o peso final dos grãos. Quanto mais cedo ocorrer a desfolha, menor será o tamanho do grão e, conseqüentemente, maior a perda de rendimento e de qualidade (Yang et al., 1991).

Em condições ótimas, o dano dessa doença pode variar de 10 a $80 \%$. Estima-se que mais de $60 \%$ da área de soja do Brasil foi atingida pela ferrugem na safra 2001/2002, o que resultou em dano de 112 mil toneladas e perdas de US\$24,70 milhões (Azevedo et al., 2004). $\mathrm{Na}$ safra 2003/2004, as perdas atribuídas a esse 
patógeno, considerando-se o custo com o controle da doença e a redução na produtividade, foram calculadas em mais de três milhões de toneladas (Yorinori, 2004).

O controle da ferrugem asiática deve compreender diversas medidas conjuntas. Quando a doença já está presente na área, o controle químico com fungicidas é, até o momento, o principal método de controle. A ferrugem asiática pode ser controlada eficientemente por fungicidas dos grupos dos triazóis e estrobilurinas e com suas misturas (Godoy \& Canteri, 2004).

No controle da ferrugem asiática, devem ser consideradas estratégias como: utilização de cultivares mais precoces, semeadas no início da época recomendada para cada região; evitar o prolongamento do período de semeadura; monitorar constantemente as lavouras; e observar se há condições de temperatura $\left(14\right.$ a $\left.28^{\circ} \mathrm{C}\right)$ e umidade relativa favoráveis ao patógeno (Yorinori \& Wilfrido, 2002). Em cultivares de ciclo precoce, os fungos têm menos tempo para causar redução da produtividade, em razão de a cultura ficar menos tempo no campo.

A resistência genética a doenças pode ser definida como a habilidade do hospedeiro em impedir o crescimento e o desenvolvimento do patógeno (Parlevliet, 1997). A resistência tem como característica a redução da taxa da epidemia, por meio da diminuição do número e tamanho das lesões, da diminuição da produção de esporos e do aumento do período latente. Isso faz com que a população do patógeno seja reduzida, diminui a quantidade de inóculo e, conseqüentemente, a intensidade da doença (Wang \& Hartman, 1992). Esse tipo de resistência torna-se visível após a resistência monogênica ter sido superada por uma nova raça do patógeno (Parlevliet, 1997). Segundo Parlevliet (1983), a seleção para resistência parcial, na presença de genes maiores para resistência, pode ser indesejável, uma vez que o efeito dos genes maiores pode suprimir o efeito dos genes menores, sob determinadas condições experimentais.

O objetivo deste trabalho foi estudar a interação da resistência genética parcial de diferentes cultivares com fungicidas, em duas épocas de semeadura, no controle da ferrugem asiática da soja, em campo.

\section{Material e Métodos}

O experimento foi realizado em área de cultivo comercial, na Fazenda Santa Rosa, a 18 55'23"S, $48^{\circ} 17^{\prime} 19^{\prime \prime} \mathrm{W}$ e $872 \mathrm{~m}$ de altitude, no Município de Uberlândia, MG.
Foi feita a coleta de dados climáticos, diariamente, por meio de um pluviômetro e de um termo-higrômetro eletrônico de máximas e mínimas, localizados na área em que o experimento foi conduzido. Foram obtidas as temperaturas máxima e mínima, umidade relativa do ar máxima e mínima e pluviosidade.

$\mathrm{O}$ delineamento experimental empregado foi o de blocos ao acaso, em esquema de parcela subdividida, com três repetições. Nas parcelas experimentais, foram dispostos os tratamentos: fungicida do grupo triazol (cyproconazole); fungicida do grupo das estrobilurinas (azoxystrobina); triazol e estrobilurina (cyproconazole + azoxystrobina) e a testemunha, sem aplicação de fungicidas. Nas subparcelas, foram utilizadas 15 cultivares de soja. As subparcelas apresentavam, para cada cultivar, uma área de $12,8 \mathrm{~m}^{2}$, com quatro linhas de $4 \mathrm{~m}$ de comprimento, com espaçamento entre linhas de $0,80 \mathrm{~cm}$. A utilização desse espaçamento foi necessária, para facilitar a montagem do experimento no campo, visto que para colocar o adubo no sulco de semeadura, utilizou-se uma semeadora com carrinhos regulados no espaçamento do milho.

$\mathrm{O}$ experimento foi conduzido em área de Latossolo Vermelho distrófico, textura argilosa, com 24 anos de cultivo de milho, soja e algodão, em sistema rotacionado, e que nos dez últimos anos foi cultivado no sistema de semeadura direta. O plantio foi realizado em duas épocas: 3/11/2005 e 6/12/2005. A utilização de duas épocas de semeadura teve o objetivo de testar a resistência das cultivares ao patógeno, sob diferentes pressões de inóculo. O plantio foi realizado em sistema de plantio direto, com 17 sementes por metro.

A adubação na semeadura foi de $550 \mathrm{~kg} \mathrm{ha}^{-1}$ de 8-28-10 (N-P-K), com 0,3 $\mathrm{kg} \mathrm{ha}^{-1}$ de boro e $0,3 \mathrm{~kg} \mathrm{ha}^{-1}$ de zinco, de acordo com as recomendações de Ribeiro et al. (1999), para solos com a mesma fertilidade do utilizado neste experimento. Os herbicidas e inseticidas, usados durante a condução do experimento, foram os recomendados para a cultura, de acordo com sua necessidade. O inóculo foi retirado de plantas de soja mantidas em casa de vegetação na Fazenda Capim Branco, da Universidade Federal de Uberlândia.

Nas duas épocas de semeadura, foram feitas inoculações de suspensão de esporos de $P$. pachyrhizi, na concentração de 25 mil esporos por $\mathrm{mL}+0,005 \%$ de Tween. As inoculações foram efetuadas durante o estádio $\mathrm{R}_{1}$ da soja, no final da tarde, por meio de pulverização da suspensão de esporos, com o uso de um pulverizador Jacto, Columbia 18-3D, com vazão de 
$200 \mathrm{~L} \mathrm{ha}^{-1}$, pressão de 50 libras pol-2, velocidade de $10 \mathrm{~km} \mathrm{~h}^{-1}$, bico Teejet turbo TTVP 110-03.As dosagens utilizadas dos fungicidas foram: azoxystrobina $0,3 \mathrm{~L} \mathrm{ha}^{-1}$ $+5 \%$ de nimbus; cyproconazole $0,3 \mathrm{~L} \mathrm{ha}^{-1}$ e mistura azoxystrobina+cyproconazole $0,3 \mathrm{~L} \mathrm{ha}^{-1}+5 \%$ de nimbus. Os fungicidas foram aplicados nas plantas por meio de pulverizador costal pressurizado a $\mathrm{CO}_{2}$, com pressão de 60 libras pol $^{-2}$, com bico Teejet turbo TTVP 110-03. A aplicação foi realizada uma única vez, de forma preventiva, no início da manhã, no mesmo dia da inoculação dos esporos do fungo, em $\mathrm{R}_{1}$, para se avaliar o grau de confiabilidade da resistência parcial em semeadura antecipada e tardia.

Foram utilizadas 15 cultivares de soja: ciclo precoce (120 a 123 dias) - IAC-100, IAC-19, MSOY-8200, MSOY-8329; ciclo médio (128 a 134 dias) - Caiapônia, CD-217, MSOY-8001, Conquista, Potenza; e ciclo tardio (150 a 164 dias) - Emgopa-313, Santa Cruz, Luziânia, UFUS-Impacta, Garantia, UFV-18. O ciclo variou conforme a época de plantio e variações climáticas da região.

As avaliações quanto ao progresso da doença iniciaram-se com o aparecimento dos primeiros sintomas, e o número de avaliações variou de três a quatro, de acordo com a variável estudada. As características avaliadas foram: incidência, severidade, nota visual da parcela, número de pústulas por centímetro quadrado, peso de mil sementes e produtividade de grãos. Para avaliar a incidência, foram selecionadas cinco plantas de cada parcela, e em cada planta foram avaliadas 12 folhas quanto à ausência ou presença de pústulas. Foram coletadas quatro folhas no terço superior da planta, quatro folhas no terço médio e quatro folhas no terço inferior da planta. Quanto à severidade, avaliouse a porcentagem de área foliar infectada por ferrugem asiática, tendo-se usado a escala diagramática desenvolvida por Polizel (2004). A nota visual da parcela foi atribuída de acordo com o grau de desfolha, de 0 a $100 \%$ para cada parcela, e foi observada por dois avaliadores. Para as características epidemiológicas, foi estimada a área abaixo da curva de progresso da doença (AACPD) (Shaner \& Finney, 1977).

Todos os dados obtidos foram analisados estatisticamente, por meio da análise de variância pelo teste $\mathrm{F}$, a $5 \%$ de probabilidade. Com as características significativas foram feitas comparações entre médias, pelo teste de Scott-Knott, por meio do SISVAR (Ferreira, 2000). Os dados obtidos no experimento foram analisados estatisticamente, pela época de semeadura e, dentro de uma mesma época, pelo ciclo das cultivares.

Com os dados do número de pústulas por centímetro quadrado e severidade (porcentagem de área foliar infectada), foi estimada a taxa de progresso absoluta média da doença (r). Quanto maior o valor de r, maior foi considerada a susceptibilidade da cultivar à doença.

\section{Resultados e Discussões}

As condições climáticas foram favoráveis à ocorrência da doença, pois houve distribuição regular de chuvas e umidade relativa do ar, sem elevações extremas e duradouras de temperatura, de acordo com os dados coletados na área experimental.

A temperatura (T), umidade relativa (UR) e pluviosidade (PL) tiveram, durante toda a condução do experimento, as variações a seguir: Tmáxima de 17,5 a $37,7^{\circ} \mathrm{C}$; Tmínima de 14,2 a $20,7^{\circ} \mathrm{C}$; UR máxima de 65 a 100\%; UR mínima de 25 a 100\%. A precipitação acumulada no período experimental foi de $1.752 \mathrm{~mm}$.

Nas cultivares de ciclo precoce, na primeira e segunda épocas de semeadura, observou-se interação significativa entre tratamentos com fungicidas e cultivares, para a área abaixo da curva de progresso da doença (AACPD) de incidência, severidade (porcentagem de área foliar infectada) e número de pústulas por centímetro quadrado. Para AACPD de severidade (nota visual da parcela), peso de mil sementes e produtividade, a interação entre tratamentos com fungicidas e cultivares não foi significativa para primeira época e, na segunda época, somente o peso de mil sementes não diferiu, significativamente, em função dos tratamentos.

$\mathrm{O}$ progresso da doença e a severidade variaram em função da época de semeadura. Nas cultivares semeadas em novembro, a doença apareceu no estádio $\mathrm{R}_{5}$ (início de formação de sementes). Nas cultivares semeadas em dezembro, a doença apareceu no estádio $\mathrm{R}_{3}$ (início de formação de vagens), apresentando maior severidade.

A média dos valores da AACPD de severidade (porcentagem de área foliar infectada) e número de pústulas por centímetro quadrado, na primeira época de semeadura, apresentaram diferenças significativas em função dos tratamentos (Tabela 1). Foi observado que a cultivar IAC-100 apresentou os menores valores de AACPD em ambas as características, tendo mantido esse comportamento até na testemunha 
(sem aplicação de fungicidas). Em relação à severidade, a mistura dos fungicidas azoxystrobina + cyproconazole apresentou bom desempenho no controle da doença, em todas as cultivares, e não foi melhor que os demais fungicidas para a cultivar MSOY-8200, e que o cyproconazole na IAC-100. Para o número de pústulas por centímetro quadrado, nas cultivares IAC-100 e IAC-19, os melhores fungicidas para o controle da ferrugem asiática foram azoxystrobina e azoxystrobina + cyproconazole. Nas cultivares MSOY-8329 e MSOY8200 , o cyproconazole apresentou os melhores resultados. Dados semelhantes foram obtidos por Azevedo (2005), que relata que a eficiência dos fungicidas no controle da ferrugem asiática varia de acordo com a cultivar.

Na segunda época de semeadura, os menores valores da AACPD da severidade (porcentagem de área foliar infectada) foram novamente da cultivar IAC-100, que manteve este comportamento em todos os tratamentos. Santos et al. (2007), em seu trabalho sobre agrupamentos para resistência parcial à ferrugem asiática, observaram que genótipos descendentes do cruzamento entre as cultivares Cristalina RCH e IAC-100 apresentaram maior resistência.

O fungicida que teve melhor desempenho, para todas as cultivares na segunda época, foi a mistura de azoxystrobina + cyproconazole (Tabela 2). A aplicação

Tabela 1. Área abaixo da curva do progresso da doença ferrugem asiática (AACPD), quanto à severidade (porcentagem de área foliar infectada) e número de pústulas por centímetro quadrado, para as cultivares de ciclo precoce, na primeira época de semeadura ${ }^{(1)}$.

\begin{tabular}{lccrr}
\hline Cultivares & $\begin{array}{c}\text { Azoxystrobina } \\
+ \text { Cyproconazole }\end{array}$ & Cyproconazole & Azoxystrobina Controle \\
\hline \multicolumn{5}{c}{ AACPD - Severidade } \\
IAC-100 & $505 \mathrm{Aa}$ & $577 \mathrm{Aa}$ & $654 \mathrm{Ab}$ & $1.040 \mathrm{Ac}$ \\
IAC-19 & $568 \mathrm{Aa}$ & $882 \mathrm{Bb}$ & $873 \mathrm{Bb}$ & $1.145 \mathrm{Bc}$ \\
MSOY-8329 & $689 \mathrm{Ba}$ & $1.085 \mathrm{Cb}$ & $1.056 \mathrm{Cb}$ & $1.233 \mathrm{Cc}$ \\
MSOY-8200 & $1.008 \mathrm{Ca}$ & $1.092 \mathrm{Ca}$ & $1.089 \mathrm{Ca}$ & $1.333 \mathrm{Cb}$ \\
\hline \multicolumn{5}{c}{$\mathrm{AACPD}-$ Número de pústulas por cm ${ }^{2}$} \\
IAC-100 & $853 \mathrm{Aa}$ & $898 \mathrm{Ab}$ & $821 \mathrm{Aa}$ & $1.614 \mathrm{Ac}$ \\
IAC-19 & $934 \mathrm{Ba}$ & $1.173 \mathrm{Bb}$ & $890 \mathrm{Ba}$ & $1.733 \mathrm{Bc}$ \\
MSOY-8329 & $1.417 \mathrm{Cb}$ & $1.350 \mathrm{Da}$ & $1.391 \mathrm{Cb}$ & $1.717 \mathrm{Bc}$ \\
MSOY-8200 & $1.390 \mathrm{Cb}$ & $1.221 \mathrm{Ca}$ & $1.454 \mathrm{Dc}$ & $1.694 \mathrm{Bd}$ \\
\hline
\end{tabular}

${ }^{(1)}$ Médias seguidas por letras iguais, minúsculas nas linhas e maiúsculas nas colunas, não diferem entre si pelo teste de Scott-Knott, a 5\% de probabilidade; os coeficientes de variação dos tratamentos com fungicidas e cultivares foram, respectivamente, 6,5 e $5,7 \%$, para severidade, e 1,5 e $1,6 \%$, para número de pústulas. dessa mistura proporcionou também as maiores médias de produtividade, em todas as cultivares, e não apresentou diferença estatística para o cyproconazole na cultivar IAC-19, e para o cyproconazole e azoxystrobina na cultivar MSOY-8329 (Tabela 2).

A cultivar IAC-100 apresentou as maiores médias de produtividade em todos os tratamentos, e não diferiu da cultivar MSOY-8200 no tratamento com azoxystrobina (Tabela 2). Assim, as observações da primeira época de semeadura, em relação à resistência genética parcial à ferrugem na cultivar IAC-100, são reforçadas, pois esta cultivar revelou menores valores de AACPD e melhores resultados de produtividade também na segunda época, com maior pressão de inóculo. Segundo Juliatti et al. (2005), o progresso da doença, nas condições brasileiras, é maior nas semeaduras tardias e em áreas irrigadas sob pivô central. Ocorre, ainda, uma redução no número de aplicações de fungicidas, quando se afasta da fonte inicial de inóculo (pivôs centrais) para áreas de sequeiro.

Nas cultivares de ciclo médio, na primeira época de semeadura, houve interação significativa entre os tratamentos, para AACPD de incidência, severidade (porcentagem de área foliar infectada) e número de pústulas por centímetro quadrado. Para a AACPD de severidade (nota visual da parcela), peso de mil sementes e produtividade, a interação não foi significativa. $\mathrm{Na}$ segunda época de semeadura, não houve interação significativa entre os tratamentos, para a AACPD de

Tabela 2. Área abaixo da curva do progresso da doença (AACPD) ferrugem asiática, quanto à severidade (porcentagem de área foliar infectada) e médias de produtividade, para as cultivares de ciclo precoce, na segunda época de semeadura ${ }^{(1)}$.

\begin{tabular}{lrcrl}
\hline Cultivares & $\begin{array}{c}\text { Azoxystrobina } \\
+ \text { Cyproconazole }\end{array}$ & Cyproconazole & Azoxystrobina & Controle \\
\hline IAC-100 & $498 \mathrm{Aa}$ & AACPD - Severidade & \\
IAC-19 & $681 \mathrm{Da}$ & $741 \mathrm{Bb}$ & $814 \mathrm{Cc}$ & $959 \mathrm{Bd}$ \\
MSOY-8329 & $642 \mathrm{Ca}$ & $879 \mathrm{Dc}$ & $779 \mathrm{Bb}$ & $966 \mathrm{Bd}$ \\
MSOY-8200 & $588 \mathrm{Ba}$ & $800 \mathrm{Cb}$ & $771 \mathrm{Bb}$ & $981 \mathrm{Bc}$ \\
\hline & & Produtividade & $\left(\mathrm{kg} \mathrm{ha}^{-1}\right)$ \\
IAC-100 & $1.457 \mathrm{Aa}$ & $1.146 \mathrm{Ab}$ & $577 \mathrm{Ac}$ & $308 \mathrm{Ad}$ \\
IAC-19 & $901 \mathrm{Ba}$ & $774 \mathrm{Ba}$ & $333 \mathrm{Bb}$ & $325 \mathrm{Ab}$ \\
MSOY-8329 & $471 \mathrm{Ca}$ & $397 \mathrm{Ca}$ & $324 \mathrm{Ba}$ & $167 \mathrm{Ab}$ \\
MSOY-8200 & $1.024 \mathrm{Ba}$ & $780 \mathrm{Bb}$ & $731 \mathrm{Ab}$ & $211 \mathrm{Ac}$ \\
\hline
\end{tabular}

(1)Médias seguidas por letras iguais, minúsculas nas linhas e maiúsculas nas colunas, não diferem entre si pelo teste de Scott-Knott, a 5\% de probabilidade; os coeficientes de variação dos tratamentos com fungicidas e cultivares foram, respectivamente, 1,9 e $2,3 \%$, para severidade, e 4,2 e $4,5 \%$, para produtividade. 
severidade (porcentagem de área foliar infectada), número de pústulas por centímetro quadrado, peso de mil sementes e produtividade. Para a AACPD de severidade (nota visual da parcela) e incidência, a interação foi significativa.

Para a incidência, na primeira época de semeadura, a cultivar Potenza apresentou características de resistência genética parcial, teve valores de AACPD relativamente baixos, em relação às demais cultivares, e não diferiu estatisticamente da 'Conquista', no tratamento azoxystrobina + cyproconazole, e das cultivares Conquista e MSOY-8001 na testemunha (Tabela 3). O tratamento com cyproconazole foi o melhor para as cultivares Potenza, Caiapônia, CD-217 e MSOY-8001. O tratamento com azoxystrobina + cyproconazole foi o melhor tratamento para todas as cultivares, com exceção da cultivar Potenza.

$\mathrm{Na}$ característica de severidade (porcentagem de área foliar infectada), a cultivar Potenza manteve também os menores valores de AACPD, em todos os tratamentos com fungicida, e não diferiu apenas da cultivar Conquista no tratamento azoxystrobina + cyproconazole, o que é indicativo de resistência genética parcial. A mistura dos fungicidas azoxystrobina + cyproconazole apresentou os melhores resultados, com menores valores de AACPD em todas as cultivares, sem diferença estatística em relação aos demais tratamentos, na cultivar Potenza, e à azoxystrobina, na cultivar MSOY-8001 (Tabela 3).

Tabela 3. Área abaixo da curva do progresso da doença (AACPD) para incidência da ferrugem asiática e severidade (porcentagem de área foliar infectada), nas cultivares de ciclo médio, na primeira época de semeadura ${ }^{(1)}$.

\begin{tabular}{lrrrr}
\hline Cultivares & \multicolumn{2}{c}{$\begin{array}{c}\text { Azoxystrobina } \\
+ \text { Cyproconazole }\end{array}$} & Cyproconazole & Azoxystrobina Controle \\
\hline Caiapônia & $270 \mathrm{Ba}$ & AACPD - Incidência & \\
Conquista & $241 \mathrm{Aa}$ & $261 \mathrm{Bb}$ & $272 \mathrm{Bb}$ & $298 \mathrm{Ac}$ \\
Potenza & $237 \mathrm{Ab}$ & $219 \mathrm{Aa}$ & $241 \mathrm{Ab}$ & $283 \mathrm{Ac}$ \\
CD-217 & $275 \mathrm{Ba}$ & $282 \mathrm{Ca}$ & $294 \mathrm{Cb}$ & $315 \mathrm{Bc}$ \\
MSOY-8001 & $248 \mathrm{Ba}$ & $260 \mathrm{Ba}$ & $277 \mathrm{Bb}$ & $289 \mathrm{Ac}$ \\
\hline \multicolumn{5}{c}{ AACPD - Severidade } \\
Caiapônia & $1.146 \mathrm{Ca}$ & $1.131 \mathrm{Cb}$ & $1.255 \mathrm{Cc}$ & $1.714 \mathrm{Cd}$ \\
Conquista & $657 \mathrm{Aa}$ & $935 \mathrm{Bc}$ & $845 \mathrm{Bb}$ & $1.392 \mathrm{Bd}$ \\
Potenza & $635 \mathrm{Aa}$ & $687 \mathrm{Aa}$ & $668 \mathrm{Aa}$ & $1.052 \mathrm{Ab}$ \\
CD-217 & $1.079 \mathrm{Ca}$ & $1.190 \mathrm{Db}$ & $1.409 \mathrm{Dc}$ & $1.731 \mathrm{Cd}$ \\
MSOY-8001 & $639 \mathrm{Ba}$ & $1.100 \mathrm{Cb}$ & $885 \mathrm{Ba}$ & $1.371 \mathrm{Bc}$ \\
\hline
\end{tabular}

${ }^{(1)}$ Médias seguidas por letras iguais, minúsculas nas linhas e maiúsculas nas colunas, não diferem entre si pelo teste de Scott-Knott, a 5\% de probabilidade; os coeficientes de variação dos tratamentos com fungicidas e cultivares foram, respectivamente, 3,1 e 3,5\%, para incidência, e 3,2 e $4,0 \%$ para severidade.
Para os valores de AACPD da severidade (nota visual da parcela), a cultivar Potenza se comportou como resistente, tendo apresentado o menor valor. Quanto aos fungicidas, os melhores resultados foram com a mistura de azoxystrobina + cyproconazole e o cyproconazole aplicado separadamente. Quanto à produtividade, notou-se que a cultivar Potenza apresentou a menor média, mesmo tendo valores de AACPD baixos. Este fato pode ser explicado pelo ciclo dessa cultivar em campo, que foi mais prolongado que o das demais cultivares, o que a deixou por mais tempo exposta à doença.

A baixa produtividade observada no experimento ocorreu em razão da alta pressão de inóculo, além de ter sido feita apenas uma aplicação de fungicida. Na região do experimento, no ano agrícola estudado, realizaram-se até cinco aplicações. Quanto aos fungicidas, não foram observadas diferenças estatísticas em relação à produtividade (Tabela 4$)$.

Conforme verificado por Juliatti et al. (2005), ao testar diferentes fungicidas no controle da ferrugem asiática, sob condições de casa de vegetação e campo, a mistura azoxystrobina + cyproconazole + nimbus na dose de 300 $+125 \mathrm{~mL}$ do produto comercial por hectare proporcionou redução no progresso da ferrugem (redução na taxa absoluta média de progresso da doença) e maior estabilidade da produção, após duas ou três aplicações consecutivas, com intervalos de 20 dias. Para os mesmos autores, as perdas pela ferrugem da soja, no Brasil,

Tabela 4. Área abaixo da curva do progresso da doença (AACPD), ferrugem asiática, quanto à severidade (nota visual da parcela), e produtividade, para as cultivares de ciclo médio, na primeira época de semeadura ${ }^{(1)}$.

\begin{tabular}{lcc}
\hline Tratamento & $\begin{array}{c}\text { AACPD - Nota visual } \\
\text { da parcela }\end{array}$ & $\begin{array}{c}\text { Produtividade } \\
\left(\mathrm{kg} \mathrm{ha}^{-1}\right)\end{array}$ \\
\hline Cultivares & $1.572 \mathrm{~d}$ & $2.689 \mathrm{a}$ \\
$\quad$ Caiapônia & $1.261 \mathrm{~b}$ & $1.825 \mathrm{c}$ \\
Conquista & $957 \mathrm{a}$ & $1.330 \mathrm{~d}$ \\
Potenza & $1.568 \mathrm{~d}$ & $2.113 \mathrm{~b}$ \\
CD-217 & $1.349 \mathrm{c}$ & $2.210 \mathrm{~b}$ \\
MSOY-8001 & 2,8 & 6,0 \\
\hline CV (\%) & $1.309 \mathrm{a}$ & $2.294 \mathrm{a}$ \\
\hline Fungicidas & $1.291 \mathrm{a}$ & $2.047 \mathrm{a}$ \\
Azoxystrobina + Cyproconazole & $1.335 \mathrm{~b}$ & $2.258 \mathrm{a}$ \\
Cyproconazole & $1.431 \mathrm{c}$ & $1.534 \mathrm{~b}$ \\
Azoxystrobina & 1,6 & 5,0 \\
Controle &
\end{tabular}

${ }^{(1)}$ Médias seguidas por letras iguais, em cada coluna, não diferem entre si pelo teste de Scott-Knott, a 5\% de probabilidade. 
podem chegar até a 25 sacos por hectare (sacos de $60 \mathrm{~kg}$ ), quando a incidência do patógeno chega a $100 \%$ e a severidade a $25 \%$.

Nas cultivares de ciclo tardio, na primeira e segunda épocas de semeadura, não houve interação entre fungicidas e cultivares, para todas as características estudadas. Na primeira época, para as características epidemiológicas estudadas, a cultivar UFUS-Impacta apresentou os menores valores de AACPD. Em relação ao peso de mil sementes, a melhor cultivar foi a Garantia e, em produtividade, a cultivar Luziânia. A menor produtividade da cultivar UFUS-Impacta também se explica pelo prolongamento no ciclo no campo, em relação às demais cultivares. No entanto, ao se analisarem as características epidemiológicas, constata-se que a UFUS-Impacta apresentou bons resultados, o que evidencia certa resistência genética parcial na cultivar (Tabela 5). Resultado semelhante foi encontrado por Juliatti et al. (2005), em que a cultivar UFUS-Impacta, proveniente do cruzamento entre as cultivares Cristalina RCH e IAC-100, apresentou resistência parcial a $P$. pachyrhizi. Azevedo (2005) também constatou resistência genética parcial à ferrugem asiática, nas cultivares MSOY-8211, UFUS-Impacta, Coodetec-208 e Emgopa-313, ao avaliar 50 genótipos de soja, em dois experimentos em casa de vegetação.

A mistura dos fungicidas azoxystrobina e cyproconazole foi que proporcionou melhor efeito nas características de incidência, severidade (porcentagem de área foliar infectada) e número de pústulas por centímetro quadrado. Quanto à severidade (nota visual da parcela), peso de mil sementes e produtividade, os fungicidas não diferiram estatisticamente (Tabela 5). Esses resultados reforçam a recomendação para o uso das misturas de triazóis e estrobilurinas.

Recomenda-se que nos programas de melhoramento genético, para a resistência genética à ferrugem asiática, devem-se utilizar genótipos com ciclo precoce, pois o ciclo menor e a existência de genes que conferem resistência parcial atuarão em conjunto na manutenção da produtividade.

Observou-se que a ferrugem asiática foi mais agressiva na segunda época de semeadura, com grande e acelerada desfolha, o que causou redução drástica na produtividade da primeira para a segunda época, o que está diretamente relacionado à grande pressão de inóculo ocorrida na segunda época de semeadura. Este resultado está de acordo com Yorinori \& Wilfrido (2002), que alertam que o controle da ferrugem asiática envolve várias estratégias de manejo, principalmente a semeadura de cultivares precoces nas épocas mais recomendadas para as regiões.

As curvas de progresso da doença (CPD), com os valores da taxa de progresso absoluta média da doença (TPAMD), para as cultivares testadas, também evidenciaram que IAC-100, UFUS-Impacta e Potenza apresentaram resistência genética parcial à ferrugem asiática, pois apresentaram CPD mais próximas ao eixo x e menores valores de TPAMD (Figura 1).

Tabela 5. Área abaixo da curva do progresso da doença (AACPD) ferrugem asiática, quanto à incidência, severidade (porcentagem de área foliar infectada), severidade (nota visual da parcela), número de pústulas por centímetro quadrado, peso de mil sementes e produtividade, para as cultivares de ciclo tardio, na primeira época de $\operatorname{semeadura}^{(1)}$.

\begin{tabular}{|c|c|c|c|c|c|c|}
\hline \multirow[t]{2}{*}{ Tratamento } & \multicolumn{3}{|c|}{ AACPD } & & \multirow{2}{*}{$\begin{array}{l}\text { Peso de mil sementes } \\
(\mathrm{g})\end{array}$} & \multirow{2}{*}{$\begin{array}{l}\text { Produtividade } \\
\quad\left(\mathrm{kg} \mathrm{ha}^{-1}\right)\end{array}$} \\
\hline & Incidência & $\begin{array}{c}\text { Área foliar } \\
\text { infectada }(\%)\end{array}$ & $\begin{array}{c}\text { Nota } \\
\text { visual da parcela }\end{array}$ & $\begin{array}{c}\mathrm{N}^{\mathrm{o}} \mathrm{de} \\
\text { pústulas por } \mathrm{cm}^{2}\end{array}$ & & \\
\hline \multicolumn{7}{|l|}{ Cultivares } \\
\hline Garantia & $11,2 \mathrm{c}$ & $961 d$ & $1.128 \mathrm{~d}$ & $1.508 \mathrm{e}$ & $114 \mathrm{a}$ & $1.360 \mathrm{~b}$ \\
\hline Luziânia & $10,6 \mathrm{~b}$ & $821 \mathrm{c}$ & $942 b$ & $1.255 \mathrm{~b}$ & $108 \mathrm{~b}$ & $1.833 \mathrm{a}$ \\
\hline Santa Cruz & $11,2 \mathrm{c}$ & $949 d$ & $1.141 \mathrm{~d}$ & $1.316 \mathrm{c}$ & $102 \mathrm{c}$ & $1.386 \mathrm{~b}$ \\
\hline Emgopa-313 & $10,4 \mathrm{~b}$ & $787 \mathrm{~b}$ & $1.000 \mathrm{c}$ & $1.239 \mathrm{~b}$ & $97 \mathrm{~d}$ & $605 \mathrm{~d}$ \\
\hline UFUS-Impacta & $10,0 \mathrm{a}$ & $679 \mathrm{a}$ & $896 a$ & $1.068 \mathrm{a}$ & $93 d$ & $909 \mathrm{c}$ \\
\hline UFV-18 & $11,0 \mathrm{c}$ & $969 d$ & $1.143 \mathrm{~d}$ & $1.351 \mathrm{~d}$ & $97 d$ & $445 \mathrm{~d}$ \\
\hline $\mathrm{CV}(\%)$ & 2,6 & 3,9 & 4,8 & 2,5 & 5,4 & 2,2 \\
\hline \multicolumn{7}{|l|}{ Fungicidas } \\
\hline Azoxystrobina + Cyproconazole & $9,6 \mathrm{a}$ & $669 \mathrm{a}$ & $988 \mathrm{a}$ & $1.076 \mathrm{a}$ & $106 a$ & $1.241 \mathrm{a}$ \\
\hline Cyproconazole & $10,6 \mathrm{~b}$ & $818 \mathrm{c}$ & $1.031 \mathrm{a}$ & $1.106 \mathrm{~b}$ & $103 a$ & $1.123 \mathrm{a}$ \\
\hline Azoxystrobina & $10,9 \mathrm{c}$ & $782 b$ & $1.052 \mathrm{a}$ & $1.245 \mathrm{c}$ & $100 \mathrm{a}$ & $1.250 \mathrm{a}$ \\
\hline Controle & $12,0 \mathrm{~d}$ & $1.171 \mathrm{~d}$ & $1.096 \mathrm{a}$ & $1.732 \mathrm{~d}$ & $98 \mathrm{a}$ & $746 \mathrm{~b}$ \\
\hline $\mathrm{CV}(\%)$ & 3,9 & 3,1 & 4,4 & 1,6 & 6,8 & 3,2 \\
\hline
\end{tabular}

${ }^{(1)}$ Médias seguidas por letras iguais, nas colunas, não diferem entre si pelo teste de Scott-Knott, a 5\% de probabilidade. 

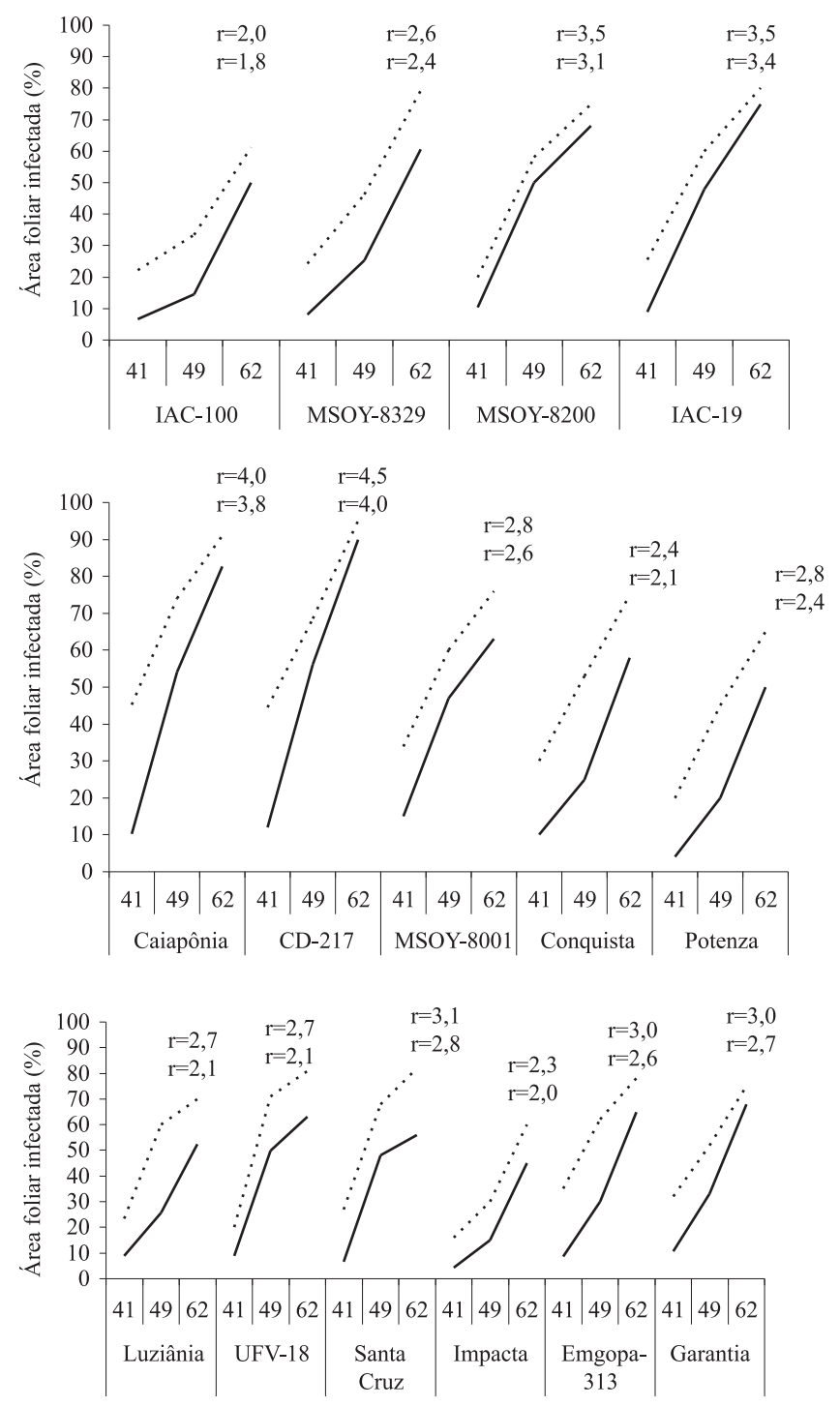

- $1^{\mathrm{a} \text { época }} \cdots \cdots 2^{\mathrm{a}}$ época

Figura 1. Porcentagem de área foliar infectada na 1a e na 2a épocas de semeadura, nas cultivares de ciclo precoce, médio e tardio, submetidas ao tratamento com azoxystrobina + cyproconazole. Os dados do eixo x referem-se ao número de dias após a inoculação, em que foram feitas as avaliações.

\section{Conclusões}

1. As cultivares IAC-100, Potenza e UFUS-Impacta apresentam resistência genética parcial à ferrugem asiática.

2. O fungicida triazol (cyproconazole) e sua mistura com o fungicida estrobilurina (azoxystrobina + cyproconazole) apresentam eficiente controle da ferrugem asiática.
3. A doença é mais agressiva na semeadura realizada tardiamente.

\section{Referências}

AZEVEDO, L.A.S.; de. Resistência parcial de genótipos de soja a Phakopsora pachyrhizi e sua interação com fungicidas. 2005. 68p. Tese (Doutorado) - Universidade Estadual Paulista, Jaboticabal. AZEVEDO, L.A.S.; JULIATTI, F.C.; BALARDIN, R.S.; SILVA, O.C. da. Programa Syntinela: monitoramento da dispersão de Phakopsora pachyrhizi e alerta contra a ferrugem asiática da soja. Campinas: Emopi Gráfica e Editora, 2004. 24p.(Boletim técnico).

FERREIRA, F.A. Manual do sistema Sisvar para análises estatísticas. Lavras: Universidade Federal de Lavras, 2000. 63p. Disponível em: <http://www.dex.ufla.br/danielff/sisvarmanual.pdf.> Acesso em: 20 dez. 2006.

GODOY, C.V.; CANTERI, M.G. Efeitos protetor, curativo e erradicante de fungicidas no controle da ferrugem da soja causada por Phakopsora pachyrhizi, em casa de vegetação. Fitopatologia Brasileira, v.29, p.97-101, 2004.

JULIATTI, F.C.; POLIZEL, A.C.; BALARDIN, R.S.; VALE, F.X.R. Ferrugem da soja: epidemiologia e manejo para uma doença reemergente. Revisão Anual de Patologia de Plantas, v.13, p.351-395, 2005.

PARLEVLIET, J.E. Can horizontal resistance be recognized in the presence of vertical resistance in plants exposed to a mixture of pathogen races? Phytopathology, v.73, p.379, 1983.

PARLEVLIET, J.E. Present concepts in breeding for disease resistance. Fitopatologia Brasileira, v.22, p.7-15, 1997. Suplemento.

POLIZEL, A.C. Quantificação de doenças foliares da soja por escalas diagramáticas e reação de genótipos. 2004. 170p. Dissertação (Mestrado) - Universidade Federal de Uberlândia, Uberlândia.

RIBEIRO, A.C.; GUIMARÃES, P.T.G.; ALVAREZ, V.H. Recomendações para o uso de corretivos e fertilizantes em Minas Gerais: 5a aproximação. Viçosa: Comissão de Fertilidade do Solo do Estado de Minas Gerais, 1999. 359p.

SANTOS, J.A.; JULIATTI, F.C.; SANTOS, V.A.; POLIZEL, A.C.; JULIATTI, F.C.; HAMAWAKI, O.T. Caracteres epidemiológicos e uso da análise de agrupamento para resistência parcial à ferrugem da soja. Pesquisa Agropecuária Brasileira, v.42, p.443-447, 2007.

SHANER, G.; FINEY, R.F. The effects of nitrogen fertilization on the expression of slow-mildewing resistance in Knox wheat. Phytopathology, v.67, p.1051-1056, 1977.

SINCLAIR, J.B.; BACKMAN, P.A. Compendium of soybean diseases. 3.ed. St. Paul: APS Press, 1989. 106p.

SOUZA, P.E.; DUTRA, M.R. Fungicidas sistêmicos. In: SOUZA, P.E.; DUTRA, M.R. Fungicidas no controle e manejo de doenças de plantas. Lavras: Ufla, 2003. p.89-142.

WANG, T.C.; HARTMAN, G.L. Epidemiology of soybean rust and breeding for host resistance. Plant Protection Bulletin, v.34, p.109-149, 1992. 
YANG, X.B.; TSCHANZ, A.T.; DOWLER, W.M.; WANG, T.C. Development of yield loss models in relation to reductions of components of soybean infected with Phakopsora pachyrhizi. Journal of Phytopathology, v.81, p.1420-1426, 1991.
YORINORI, J.T.; WILFRIDO, M.P. Ferrugem da soja: Phakopsora pachyrhizi Sydow. Londrina: Embrapa Soja, 2002.

YORINORI, T.J. Ferrugem da soja: panorama geral. In: CONGRESSO BRASILEIRO DE SOJA, 3., 2004, Londrina. Anais. Londrina: Embrapa Soja, 2004. p.1299-1307.

Recebido em 14 de maio de 2007 e aprovado em 23 de agosto de 2007 